\title{
A comparative study of two different techniques of subcutaneous tissue closure in abdominal surgery
}

\author{
Jyotsna S. Dwivedi' ${ }^{1}$, Alka S. Gupta ${ }^{2}$, Sachin H. Pardeshi ${ }^{2 *}$
}

\author{
${ }^{1}$ Department of Obstetrics and Gynecology, LTMMC and GH, Sion, Mumbai, Maharashtra, India \\ ${ }^{2}$ Department of Obstetrics and Gynecology, Seth G. S. Medical College and K. E. M. Hospital, Parel, Mumbai, \\ Maharashtra, India
}

Received: 29 September 2017

Accepted: 30 October 2017

\section{*Correspondence:}

Dr. Sachin H. Pardeshi,

E-mail: sachinhpardeshi@gmail.com

Copyright: ( $)$ the author(s), publisher and licensee Medip Academy. This is an open-access article distributed under the terms of the Creative Commons Attribution Non-Commercial License, which permits unrestricted non-commercial use, distribution, and reproduction in any medium, provided the original work is properly cited.

\begin{abstract}
Background: Surgical access to abdomen is required for many operative procedures. The subcutaneous tissue of the anterior abdominal wall can either be sutured or left unsutured with drain in situ. The purpose of this study was to compare the two methods of closure of the subcutaneous tissue and determine the benefit of one over the other.

Methods: The study was conducted in a tertiary care centre with sample size of 30 each in study and control group. Patients fulfilling the inclusion criteria were selected and depending on the randomisation the closure of subcutaneous tissue was done either by polyglactin 910, 2-0 or left unsutured with indigenously designed syringe suction drain kept in situ. The patients were followed up till the day of suture removal and further in case of any complications.

Results: Total duration taken for the procedure was significantly increased in the study group. There was a significant level of discomfort among the participants due to drain. The rate of surgical site infection, hospital readmission morbidity was significantly higher in the study group.

Conclusions: The type of drain studied was indigenously designed where the closed system was not maintained during charging the drain, hence further studies need to be conducted which will compare this with the other closed suction drains to determine the difference in the risk of wound complications.
\end{abstract}

Keywords: Polyglactin 910, Surgical drains, Surgical site infections, Wound healing

\section{INTRODUCTION}

Surgical access to abdomen is required for many operative procedures. The basic knowledge of anatomy governs the closure of all abdominal incisions. The anterior abdominal wall consists of the following layers from inside out-peritoneum, extra-peritoneal fascia (deep fascia), muscle, superficial fascia, subcutaneous tissue and skin. ${ }^{1}$ The various muscular and fascial layers make up the anatomical planes of the abdomen. A midline vertical incision is the most commonly used route for the access to the abdominal cavity. It is of clinical importance to be aware of the various layers and levels of tissue for abdominal wound closure. The wound healing process in surgical wound depends upon the intrinsic properties of the patient and also upon the type of wound such as whether it is clean, clean-contaminated, contaminated or dirty.

In this study we tried to compare the two different modalities of subcutaneous tissue closure and determine the benefit of using one method over the other.

\section{METHODS}

This study was an observational comparative study conducted on indoor patient in a tertiary care centre from July 2014 to October 2015. Institutional Ethics 
Committee's permissions were obtained. Consent was administered to each patient by the co-investigator.

A total of 60 cases were included in the study.

\section{Inclusion criteria}

Patients fulfilling the following criteria were included in the study:

- $\quad$ Of age 18 and up to 70 years

- Patients having midline vertical infra-umbilical incision

- Pre-operative hemoglobin level of $10 \mathrm{gm} \%$ and above

- Patients who were immune competent, seronegative status, not on chemotherapy/radiotherapy/oral/ parenteral corticosteroids

- Patients who had primary clean-cut wound

- Patients who were willing to participate in the study.

\section{Exclusion criteria}

- Patients who did not consent for the study

- Patients with pre-op hemoglobin of less than 10 gm $\%$

- Patients having pfannensteil incision

- Patients addicted to tobacco or betel nut chewing, alcohol consumption

- Patient who were immune compromised such as on chemotherapy or radiotherapy or on oral/or parenteral corticosteroids and HIV positive status

- Patients whose BMI was $<25 \mathrm{~kg} / \mathrm{m}^{2}$.

\section{Study group}

Patients whose subcutaneous tissue was left unsutured and syringe suction drain was kept in situ. The drain was designed indigenously.

\section{Control group}

Patients whose subcutaneous tissue was sutured using polyglactin $9102-0$.

\section{Statistical analysis}

Data were statistically described in terms of mean $( \pm \mathrm{SD})$, frequencies (number of cases) and percentages when appropriate. Klomogorov-Smirnov test was used for testing the data for normal distribution. Comparison of quantitative variables between the study groups was done using Student $t$ test for independent samples if normally distributed. Mann-Whitney U test was used for nonnormally distributed quantitative and ordinal data.

Chi square test was used for comparing categorical data performed. When the expected frequency is less than 5, exact test was used. A probability value ( $p$ value) less than 0.05 was considered statistically significant. Computer programs Microsoft Excel 2007 and SPSS version 17 were used for statistical analysis.

\section{RESULTS}

The age is an important factor in wound healing and hence both the study and control group had patients in similar age range to avoid confoundation.

Table 1: Comparison of the age.

\begin{tabular}{|lll|}
\hline Group & Mean age (years) & p-value \\
\hline Control & 31.20 & 0.29 \\
\hline Study & 34.17 & \\
\hline
\end{tabular}

Mean age distribution in control group is 31.20 years and in study group it is 34.17 years.

Mean hemoglobin levels in both study and control group were compared and were found to be significantly different.

Table 2: Mean haemoglobin level in cases and control.

\begin{tabular}{|lll|}
\hline Group & Mean haemoglobin $($ gm \% $)$ & p-value \\
\hline Control & 10.91 & 0.02 \\
\hline Study & 11.42 & \\
\hline
\end{tabular}

The hemoglobin in study group was $11.42 \mathrm{gm} \%$ and that in the control group was $10.91 \mathrm{gm} \%$.

BMI of the patients was compared in the study and control group. The body mass index is considered as one of the factors for good wound healing. The patients in both study and control group belonged to overweight and obese group as per BMI criteria.

Table 3: BMI of the participants.

\begin{tabular}{|c|c|c|}
\hline Group & BMI $\left(\mathrm{kg} / \mathrm{m}^{2}\right)$ mean & p-value \\
\hline Control & 29.69 & \multirow{2}{*}{0.33} \\
\hline Study & 30.36 & \\
\hline
\end{tabular}

BMI of patients in study group is $30.36 \mathrm{~kg} / \mathrm{m}^{2}$ and that in control group was $29.69 \mathrm{~kg} / \mathrm{m}^{2}$.

Mean duration of surgery was assessed and it was more in the study group than in the control group. The process of assembling and putting a subcutaneous drain increased the duration of surgery.

Table 4: Mean duration of the surgery.

\begin{tabular}{|lll} 
Group & $\begin{array}{l}\text { Mean duration of } \\
\text { surgery (in hours) }\end{array}$ & p-value \\
\hline Control & 1.37 & 0.04 \\
\hline Study & 1.71 & \\
\hline
\end{tabular}


The study group had mean duration of 1.71 hours which was more as compared to control group.

Maximum patients in both the group were Housewives by occupation. The occupation of patients in the study and control group was considered as it could be one of the important factors in would healing.

Table 5: Occupation of the participants.

\begin{tabular}{|lll|}
\hline Group & Housewife & Working \\
\hline Control & 24 & 6 \\
\hline Study & 28 & 2 \\
\hline
\end{tabular}

Table 6: Post op features in ward.

\begin{tabular}{|llll|}
\hline Group & Fever $(\%)$ & $\begin{array}{l}\text { Signs of } \\
\text { inflammation } \\
(\%)\end{array}$ & $\begin{array}{l}\text { Soakage of } \\
\text { wounds } \\
(\%)\end{array}$ \\
\hline Control & 3.3 & 3.3 & 0 \\
\hline Study & 13.3 & 13.3 & 10 \\
\hline
\end{tabular}

Maximum participants in both the groups were housewives by occupation
Post operatively presence of fever, signs of inflammation and soakage of wounds were compared. As it can be seen the percentage of fever, signs of inflammation and soakage of wounds was higher in the group with drain insertion.

Fever, signs of inflammation such as redness and soakage of wound was compared, and it was found to be more in study group similar to the fever, signs of inflammation such as redness and soakage of wound was compared and it was found to be more in study group similar to various other studies as mentioned in Table 14. Suture removal in both the groups was done between days 7-14.

Table 7: Mean day of suture removal.

\begin{tabular}{|lll} 
Group & Mean day of suture removal & p-value \\
\hline Control & 8.57 & 0.63 \\
\hline Study & 8.43 & \\
\hline
\end{tabular}

Mean day of suture removal. The suture removal was done on day 7 in cases with no intra op complications, whereas for those with complications like post-op low haemoglobin, fever, suture removal was delayed.

Table 8: Features observed on suture removal.

\begin{tabular}{|lllll|}
\hline Group & $\begin{array}{l}\text { Signs of inflammation } \\
(\%)\end{array}$ & $\begin{array}{l}\text { Wound discharge } \\
(\%)\end{array}$ & $\begin{array}{l}\text { Culture documented } \\
\text { infection }(\%)\end{array}$ & $\begin{array}{l}\text { Other complaints } \\
(\%)\end{array}$ \\
\hline Control & 10.0 & 10 & 3.3 & 0 \\
\hline Study & 36.7 & 26.7 & 20 & 23.3 \\
\hline
\end{tabular}

The postoperative period was analysed for the presence of wound discharge, fever, redness, erythema, pain at the suture site.

In the study group the patients had more incidence of fever, discharge, inflammation, discomfort due to placement of drain. Signs of inflammation, wound discharge and culture documented infection was more in the study group.

Due to placement of drain the chances of ascending infection of the drain site and suture site was more as observed here. Wound dehiscence and secondary suturing was seen in study group whereas the control group didn't have such complications.

Table 9: Wound complications observed.

\begin{tabular}{|lll|}
\hline Group & Control & Study \\
\hline Wound dehiscence (\%) & 0 & 13.3 \\
\hline Secondary suturing (\%) & 0 & 13.3 \\
\hline
\end{tabular}

Wound complications observed in both groups. Wound dehiscence was seen in study group in $13.33 \%$ and also secondary suturing was required in $13.33 \%$.
Table 10: Organisms grown in culture.

\begin{tabular}{|ll|}
\hline Organism & Total no. of cases \\
\hline MRSA & 1 \\
\hline Klebsiella pneumonia & 1 \\
\hline Eschericia coli & 3 \\
\hline $\begin{array}{l}\text { Enterococus faecalis } \\
\text { Coagulase negative staph. } \\
\text { aureus }\end{array}$ & 1 \\
\hline
\end{tabular}

Culture documented infections were seen in the study group.

Total number of cases and respective organisms involved. Various organisms were found in the wound swab sent from the study group, wound complicated cases. Maximum of them were E. coli.

The drain removal was done when the drain output reduced to less than $50 \%$ of the previous day drain output. In the study group, maximum drains were removed on day 2 , only 3 patients had drain removal done on day 4 . In these 3 patients the wound discharge persisted uptil post-op day 4 . 
Table 11: No. of cases with dehiscence on drain removal on subsequent days.

\begin{tabular}{lll}
$\begin{array}{l}\text { Day of drain } \\
\text { removal }\end{array}$ & $\begin{array}{l}\text { No. of drains } \\
\text { removed } \\
N=30\end{array}$ & $\begin{array}{l}\text { \% of cases with } \\
\text { wound dehiscence }\end{array}$ \\
\hline Day 2 & 15 & 6.667 \\
\hline Day3 & 12 & 8.333 \\
Day4 & 3 & 66.667 \\
\hline
\end{tabular}

Table 12: Total rate of surgical site infections.

\begin{tabular}{|ll|}
\hline Group & Rate of SSI (\%) \\
\hline Control & 10 \\
\hline Study & 26.67 \\
\hline
\end{tabular}

It was observed that the delay in drain removal led to increased chances of wound complications. The rate of surgical site infections was $10 \%$ in control group and $26.67 \%$ in the study group. In this study it was found that due to increased chances of ascending infection following drain insertion the surgical site infection rate increased.
It can be seen from the above figure that rate of surgical site infection was more in study group similar to the study of Magann et al.

\section{DISCUSSION}

The surgical access to the abdomen is required for many procedures. The various muscular and fascial layers make up the anatomical planes of the abdomen. ${ }^{1}$ Various methods of closure of the layers of the abdomen have been described and are in practice. ${ }^{2}$ It is of clinical importance to be aware of the various layers and levels of tissue for abdominal wound closure.

The wound healing process in surgical wound depends upon the intrinsic properties of the patient and also upon the type of wound such as whether it is clean, cleancontaminated, contaminated or dirty. The vascular supply to the subcutaneous tissue is restricted and thus escalates the chances of soft tissue infection. ${ }^{3}$

Table 13: Comparison of various parameters studied in control and study group.

\begin{tabular}{|c|c|c|c|c|}
\hline Parameter & $\begin{array}{l}\text { Control group } \\
\text { (subcutaneous suturing) }\end{array}$ & $\begin{array}{l}\text { Study group } \\
\text { (drain) }\end{array}$ & P value & Significance \\
\hline Age & 31.20 & 34.17 & 0.29 & Not significant \\
\hline BMI & 29.69 & 30.36 & 0.33 & Not significant \\
\hline Haemoglobin & 10.91 & 11.42 & 0.02 & Significant \\
\hline Duration of surgery & 1.37 & 1.71 & 0.04 & Significant \\
\hline Day of suture removal & 8.57 & 8.43 & 0.63 & Not significant \\
\hline \multicolumn{5}{|l|}{ Parameters studied in post op period } \\
\hline Fever & 1 & 4 & 0.35 & Not significant \\
\hline Soakage of wound & 0 & 3 & 0.23 & Not significant \\
\hline Signs of inflammation & 1 & 4 & 0.35 & Not significant \\
\hline $\begin{array}{l}\text { Other complaints (discomfort due to } \\
\text { drain placement) }\end{array}$ & 0 & 7 & $<0.01$ & Significant \\
\hline \multicolumn{5}{|c|}{ Parameters studied on day of suture removal } \\
\hline Signs of inflammation & 3 & 11 & $<0.05$ & Significant \\
\hline Wound discharge & 3 & 8 & 0.18 & Not significant \\
\hline Culture documented infection & 1 & 6 & 0.01 & Significant \\
\hline Wound dehiscence & 0 & 4 & 0.12 & Not significant \\
\hline Need for secondary suturing & 0 & 4 & 0.12 & Not significant \\
\hline Pain/discharge at the drain site & 0 & 2 & 0.49 & Not significant \\
\hline Hospital readmission & 0 & 4 & 0.12 & Not significant \\
\hline Total rate of surgical site infection & $10 \%$ & $26.67 \%$ & - & - \\
\hline
\end{tabular}

The subcutaneous tissue can be sutured or left unsutured. The purpose of subcutaneous tissue closure is to decrease the space available for developing of seroma or any collection thus preventing the infection in this layer. Subcutaneous tissue layer can be closed with either suturing the layer with an absorbable suture material or by placing a suction drain in situ. Body mass index of the patient is one amongst the various parameters of the patient which affects the wound healing. Absorbable suture material such as Polyglactin 910, with good tensile strength can be used for closure of subcutaneous tissue layer in order to decrease the inflammation. ${ }^{4}$ However not suturing the subcutaneous layer and placing a suction drain in to the subcutaneous layer and directly closing the 
skin in order to decrease the foreign body reaction and faster as well as easier closure of the skin can also be considered. ${ }^{5}$ Surgical drains are of various types: open or closed; active or passive. Open drains include corrugated rubber or plastic sheets. Closed drains are again of two types: active and passive drains. Active drains are further of two types: high and low-pressure suction drains. Drains help in prevention of bacterial ascension and also help in proper apposition of skin to subcutaneous tissue. ${ }^{6}$ The fact remains that though there have been multiple methods of closure of the subcutaneous tissue, the ideal method for closure of the subcutaneous tissue has not been advised. Wound complications can occur despite following strict asceptic techniques.

We studied various databases and came across metaanalyses in which multiple studies had been evaluated. Each study had investigated the effect of use of a particular type of drain and compared it to another type of drain or if not drain then another method of closure of the subcutaneous tissue. Inspite of the numerous studies performed consensus is still lacking as to the preferred method of approximation of the subcutaneous tissue. The analysis pertaining only to studies in which subcutaneous drain was compared with subcutaneous suturing was included for our comparative study. Various parameters have been compared. We have tried to cover these details in our study with the aim of establishing the need of subcutaneous closure or drain insertion for abdominal surgeries.

Out of the 30 participants in each group, the mean age of patients in both groups was between 31-35 years as shown in Table 1. All the patients belonged to middle social economic class. The mean body mass index of patients in control group was $29.69 \mathrm{~kg} / \mathrm{m}^{2}$ and that in study group was $30.36 \mathrm{~kg} / \mathrm{m}^{2}$. The hemoglobin level in the control group was $10.91 \mathrm{gm} \%$ and in study group was $11.42 \mathrm{gm} \%$.

The past medical and surgical history of the participants was evaluated so as to note whether there was an association between the past histories and outcomes. The outcomes in both the groups were studied. We had hypothesized that patients who undergo prophylactic drain insertion would have less rate of surgical site infection. We had also hypothesized that prophylactic draining would help in proper wound healing and hence reduce the burden on hospital expenses. But none of these hypotheses proved to be correct and statistics showed that irrespective of the past medical and surgical history of the patient, the rate of surgical site infections and wound healing abnormalities were comparable in both the groups.

Time taken for the procedure was comparable between the two groups with the mean time taken in control group being 1.37 and that for study group being 1.71 . This is possibly because the preparation of the syringe suction drain, and its insertion might have increased the duration of procedure in the study group, thus increasing the chances of infection in the study group. The overall satisfaction of the patient was assessed by verbal questioning post operatively. The patients in the study group had subjective differences in the level of comfort due to the dangling drain. There were no mortalities or intra-operative complications in any of the groups. The participants were evaluated in the post-operative period for development of features of inflammation and infection. Two patients had wound discharge in the control group and eight patients had wound discharge of which four patients developed wound dehiscence in the study group.

Out of the patients with wound discharge the culture documented infection was seen in total seven patients and three were sterile discharges. The organisms isolated from the discharge were Escherichia coli, MRSA, CONS, Enterococcus faecalis, Klebsiella pneumoniaea.

The patients received parenteral antibiotics as per the hospital infection control policy for three days. The antibiotics used covered the gram positive, gram negative organisms and both aerobic and anaerobic organisms. The post-operative course in ward was observed for fever, soakage of wounds, signs of inflammation and in the study group the amount of drain output recorded. In the control group only one patient had fever whereas in the study group four patients had fever episodes in the post-operative period. There were total three patients in the study group who had soakage of wound and required dressing to be repeated. The signs of inflammation in the form of induration, tenderness, redness, pain at the site of incision were observed in one patient in control group and four patients in the study group. Out of total thirty patients in the study group, seven patients were uncomfortable with the drain which is statistically significant. The cause of fever could be the extra duration of surgery in the study group and thus increased chances of wound infection. Also, the drain required charging twice a day which meant the parts of the drain to be dismantled and then reassembled. Probably, this was also a source of infection. On the day of suture removal patients were evaluated again for signs of inflammation, soakage of wound, wound dehiscence, wound discharge, need for readmission, need for secondary suturing.

It was observed that the patients in whom the drain was kept for longer duration had increased rate of wound dehiscence such as: out of fifteen patients with drain removal done on day 2 , only one patient had wound dehiscence, of the twelve patients with drain removal done on day 3 , one patient had wound dehiscence whereas out of three patients with drain removal done on day 4, two patients had wound dehiscence. The overall incidence of surgical site infection was found to be more in the study group as compared to the control group. Present study was compared with other studies and the data generated is presented in Table 14. 
Table 14: Comparison with other similar studies.

\begin{tabular}{|c|c|c|c|c|c|c|}
\hline Parameter & Present study & Allaire $2000^{7}$ & Magann $2002^{8}$ & Kumar 20049 & Cardosi $2006^{10}$ & Kaya E $2010^{11}$ \\
\hline Study design & $\begin{array}{l}\text { Single blinded } \\
\text { retro prospective } \\
\text { randomised } \\
\text { observational } \\
\text { study }\end{array}$ & $\begin{array}{l}\text { Prospective } \\
\text { randomised } \\
\text { clinical trial }\end{array}$ & $\begin{array}{l}\text { Prospective } \\
\text { randomised } \\
\text { clinical trial }\end{array}$ & $\begin{array}{l}\text { Randomizer } \\
\text { control trial }\end{array}$ & $\begin{array}{l}\text { Prospective } \\
\text { randomised } \\
\text { control trial }\end{array}$ & $\begin{array}{l}\text { Prospective } \\
\text { randomised } \\
\text { clinical trial }\end{array}$ \\
\hline Sample size & $60(30)$ & $76(24)$ & $964(590)$ & $148(46)$ & 225 & $402(210)$ \\
\hline $\begin{array}{l}\text { Trial } \\
\text { conducted at }\end{array}$ & $\begin{array}{l}\text { Tertiary care } \\
\text { centre in India } \\
\text { from July 2014- } \\
\text { October } 2015\end{array}$ & $\begin{array}{l}\text { USA from } \\
1995-97 .\end{array}$ & $\begin{array}{l}\text { USA from } \\
\text { 1998- } 2001\end{array}$ & $\begin{array}{l}\text { Not } \\
\text { mentioned }\end{array}$ & $\begin{array}{l}\text { South Florida } \\
\text { and East Tenesse } \\
\text { State University }\end{array}$ & Turkey \\
\hline Study groups & $\begin{array}{l}\text { Syringe suction } \\
\text { drain placed in the } \\
\text { subcutaneous } \\
\text { tissue }\end{array}$ & $\begin{array}{l}\text { Closed suction } \\
\text { drain placed }\end{array}$ & $\begin{array}{l}\text { Subcutaneous } \\
\text { drain placed }\end{array}$ & $\begin{array}{l}\text { Subcutaneous } \\
\text { closed drain }\end{array}$ & $\begin{array}{l}\text { Closed suction } \\
\text { drain placed }\end{array}$ & $\begin{array}{l}\text { Closed suction } \\
\text { drain placed }\end{array}$ \\
\hline $\begin{array}{l}\text { Drain insertion } \\
\text { technique }\end{array}$ & $\begin{array}{l}\text { Syringe suction } \\
\text { drain indigenously } \\
\text { designed in the } \\
\text { hospital set up } \\
\text { with the available } \\
\text { material used. }\end{array}$ & $\begin{array}{l}\text { Closed suction } \\
\text { drain was used }\end{array}$ & $\begin{array}{l}\text { Subcutaneous } \\
\text { drain placed }\end{array}$ & $\begin{array}{l}\text { Subcutaneous } \\
\text { closed } \\
\text { suction drain }\end{array}$ & $\begin{array}{l}\text { Closed suction } \\
\text { drain was used }\end{array}$ & $\begin{array}{l}\text { Closed suction } \\
\text { drain was used. }\end{array}$ \\
\hline $\begin{array}{l}\text { Demographic } \\
\text { differences in } \\
\text { the groups } \\
\text { studied }\end{array}$ & No difference & Not studied & No difference & Not specified & $\begin{array}{l}\text { No statistical } \\
\text { differences }\end{array}$ & $\begin{array}{l}\text { No statistical } \\
\text { difference }\end{array}$ \\
\hline BMI & $>25 \mathrm{~kg} / \mathrm{m}^{2}$ & Not specified & Not specified & Not specified & Not specified & Not specified \\
\hline $\begin{array}{l}\text { Subcutaneous } \\
\text { fat thickness }\end{array}$ & $2.5 \mathrm{~cm}$ & $2 \mathrm{~cm}$ & $\geq 2 \mathrm{~cm}$ & $>2 \mathrm{~cm}$ & $3 \mathrm{~cm}$ & Not specified \\
\hline $\begin{array}{l}\text { Intra operative } \\
\text { complications }\end{array}$ & None & Not mentioned & Not studied & Not studied & Not studied & Not studied \\
\hline $\begin{array}{l}\text { Drain removed } \\
\text { on day }\end{array}$ & $\begin{array}{l}\text { Drain output } \\
<50 \% \text { of previous } \\
\text { day }\end{array}$ & $\begin{array}{l}\text { In } 72 \text { hours or } \\
\text { if drain output } \\
<50 \mathrm{ml} \text { in } 24 \\
\text { hours. }\end{array}$ & Not specified & $\begin{array}{l}\text { Not } \\
\text { mentioned }\end{array}$ & Not mentioned & Day 3 \\
\hline Fever & $\begin{array}{l}4(13.3 \%) \\
\text { p value } 0.35\end{array}$ & Not specified & Not studied & $5 / 46$ & Not studied & Not studied \\
\hline $\begin{array}{l}\text { Signs of } \\
\text { inflammation }\end{array}$ & $\begin{array}{l}4(13.3 \%) \\
\text { p value } 0.35\end{array}$ & Not specified & Not specified & Not specified & Not specified & Not specified \\
\hline $\begin{array}{l}\text { Soakage of } \\
\text { wounds }\end{array}$ & $\begin{array}{l}3(10 \%) \\
\text { p value } 0.25\end{array}$ & Not specified & Not specified & Not specified & Not specified & Not specified \\
\hline $\begin{array}{l}\text { Culture } \\
\text { documented } \\
\text { infection }\end{array}$ & $\begin{array}{l}6(20 \%) \\
\mathrm{p} \text { value } 0.01\end{array}$ & 0 & $14(7.216 \%)$ & $2(4.34 \%)$ & Not specified & $5.7 \%$ \\
\hline $\begin{array}{l}\text { Wound } \\
\text { complications }\end{array}$ & $8(26.6 \%)$ & $\begin{array}{l}\text { Not } \\
\text { differentiated }\end{array}$ & $6(3.09 \%)$ & $4(8.69 \%)$ & $17.9 \%$ & Not specified \\
\hline $\begin{array}{l}\text { Wound } \\
\text { dehiscence }\end{array}$ & $\begin{array}{l}4(13.3 \%) \\
\text { p value } 0.12\end{array}$ & Not specified & Not specified & Not specified & $14.9 \%$ & Not specified \\
\hline $\begin{array}{l}\text { Hospital } \\
\text { readmission }\end{array}$ & $4 \mathrm{p}$ value 0.12 & Not specified & Data could no & obtained & & \\
\hline
\end{tabular}

Hence, from the Table 14 we can infer that post-operative complications were assessed in detail in the present study when compared to the other international studies. We could not study follow up details of the patients regarding the long-term effects of the procedure due to time constraints. The drain was indigeniously made using syringe and was thought to reduce the cost of hospital expenses as compared to other drains. ${ }^{12}$ But judging by the rate of wound disruptions and dehiscence which was comparable in the two groups, it is safe to conclude that the procedure of prophylactic drain insertion for subcutaneous tissue approximation does not help to reduce the surgical site infection as was postulated. Though there was significant difference in the level of comfort in both the groups of the patients, to conclude that the drains should not be prophylactically used, will 
require further meta analyses of the various primary studies available.

\section{CONCLUSION}

In conclusion to this study, we found that there was increased rate of surgical site infection in the patients who had syringe suction drain insertion done for prophylactic seroma, and bacterial infection prevention. The type of drain studied was indigenously designed and the closed system was not maintained during charging the drain, hence further studies need to be conducted which will compare this with the other closed suction drains to determine the difference in the risk of wound complications.

Funding: No funding sources Conflict of interest: None declared

Ethical approval: The study was approved by the Institutional Ethics Committee

\section{REFERENCES}

1. Harmon LA, HusenVR, Roberts EK, Abdominal closure. Medscape. 2017. Available at https://emedicine.medscape.com/article/1961789overview

2. Ranbhari NN, Knebel P, Diener MK, Seidlmayer C, Ridwelski K, Stoltzing H, et al. Current practice of abdominal wall closure in elective surgery - is there any consensus?. BMC Surg. 2009;9:8.

3. Bryan BM, Ali T, Stephen FJ. Incisions, closures, and management of the abdominal wound. In: Zinner MJ, Ashley SW, eds. Maingot's Abdominal Operations. United States: McGraw-Hill Companies, Inc; 2007.

4. James J, Burke II, Gallup DG. Incisions for Gynecologic Surgery. In: Rock JA, Jones HW III, eds. TeLinde's Operative Gynecology. $10^{\text {th }}$ ed. New Delhi: Wolters Kluwer Health-Lippincott Williams and Wilkins; 2008:251-2.

5. Anderson ER, Gates S. Techniques and materials for closure of the abdominal wall in caesarean section
(Review). The Cochrane Collaboration. Published by John Wiley and Sons Ltd. 2009:16-9.

6. Mohammad S. Surgical drains power point presentation. Available at http://www.authorstream.com/Presentation/aSGuest3 1302-271310-surgical-drains-sumaya-mohd-sciencetechnology-ppt-powerpoint/

7. Allaire AD, Fisch J, Macmohan MJ. Subcutaneous drain versus suture in obese women undergoing caesarean delivery. J Reprod Med. 2000;45:327-31.

8. Magann EF, Chauhan SP, Palenik RS, Bufkin L, Martin Jr JN, Morrison JC. Subcutaneous stitch closure versus subcutaneous drain to prevent wound disruption after caesarean delivery: a randomized clinical trial. Am J Obstet Gynecol. 2002;186(6):1119-23.

9. Kumar SA. Subcutaneous drain versus subcutaneous stitch closure to prevent wound disruption after caesarean section. J Obstet Gynecol India. 2004:54(3):237-42.

10. Cardosi RJ, Drake J, Holmes S, Tebes SJ, Hoffman MS, Fiorica JV, et al. Subcutaneous management of vertical incisions with 3 or more centimeters of subcutaneous fat. Am J Obstet Gynecol. 2006;195(2):607-14.

11. Kaya E, Paksoy E, Ozturk E, Sigirli D, Bilgel H. Subcutaneous closed suction drainage does not affect surgical site infection rate following elective abdominal operations: a prospective randomized clinical trial. Acta Chirurgica Belgica. 2010;4:45762.

12. Dwivedi JS, Gupta AS. Syringe suction vacuum drain: a cheap alternative. JPGO. 2014;1(4). Available at http://www.jpgo.org/2014/04/syringesuction-vacuum-drain-cheap.html

Cite this article as: Dwivedi JS, Gupta AS, Pardeshi $\mathrm{SH}$. A comparative study of two different techniques of subcutaneous tissue closure in abdominal surgery. Int J Reprod Contracept Obstet Gynecol 2017;6:5512-8. 